Article

\title{
The Dialectics of Care: Communicating Ethical Trade in Poland
}

\author{
Kinga Polynczuk-Alenius \\ Media and Communication Studies, University of Helsinki, 00014 Helsinki, Finland; E-Mail: kinga.polynczuk@helsinki.fi
}

Submitted: 24 November 2017 | Accepted: 16 April 2018 | Published: 29 June 2018

\begin{abstract}
This article is an empirical exploration of how ethical trade organisations draw on and appropriate in their communication the moral repertoire of ethical trade. Theoretically, it employs the notion of the "dialectics of care" to examine the tactics used in ethical trade communication to reconcile care for oneself and one's close ones with care for distant producers. Empirically, this article is based on the discourse-theoretical analysis of two interviews with the representatives of Polish ethical trade organisations: (1) a fair trade firm, Pizca del Mundo, and (2) an NGO, the Institute for Global Responsibility. The analysis finds that ethical trade organisations seek to harmonise care for distant producers with the interests of the Polish public through (1) embedding it into the discourse of product quality, or (2) linking it to care for oneself, one's family and society while raising awareness of the global interconnectedness.
\end{abstract}

\section{Keywords}

care; discourse-theoretical analysis; ethical trade; fair trade; interviews; metageography; moral education; Poland

\section{Issue}

This article is part of the issue "Media and Communication between the Local and the Global", edited by Jessica Gustafsson (Södertörn University, Sweden) and Kinga Polynczuk-Alenius (University of Helsinki, Finland).

(C) 2018 by the author; licensee Cogitatio (Lisbon, Portugal). This article is licensed under a Creative Commons Attribution 4.0 International License (CC BY).

\section{Introduction}

This article is an empirical exploration of how two ethical trade organisations in Poland draw on the moral repertoire of ethical trade in their communication. It proposes and employs the notion of the "dialectics of care" to investigate how care, understood as an ethical and emotional concern for others (Silk, 1998; Smith, 1998), is conceptualised and negotiated in ethical trade communication to reconcile individuals' own interests and the interests of their family members with the interests of distant producers. This is important, because ethical trade stems from the recognition of the shortcomings of the current North-South trade that is devised to satisfy Northern consumers' perceived need for the lowest possible prices at the cost of driving Southern producers into ever-direr poverty (see Miller, 2003). To remedy the situation, ethical trade proposes a wide set of initiatives that are aimed at reconstructing global trade as a web of more just and equitable relationships (Hudson \& Hudson, 2003; Raynolds \& Bennett, 2015). Here, the underlying assumption is that the late-capitalist economic and trade systems are neither natural nor absolute. Rather, they are constructed and, therefore, open for renegotiation.

Translating structural efforts into moral terms, ethical trade attempts to reclaim trade as a nexus of relationships among human actors in the context of global commodity chains in which human labour figures only as an "inanimate" aspect of production (Smith, 1998, p. 20). This is done, I propose, through communication, broadly conceived as a "symbolic process whereby reality is produced, maintained, repaired, and transformed" (Carey, 2008 , p. 19). In this view, communication is not about mere transmission of information and messages via technology. Instead, communication is also performative: it creates a specific vision of the world and-through mediation rather than transmission (Silverstone, 2002)-calls into being subjects willing to inhabit this world. Building on that, I approach ethical trade communication as a project of moral education geared towards rendering the predicament of distant producers as being worthy of attention, emotion and action (see Chouliaraki, 2008).

While the moral outlook proposed by ethical trade communication is a complex combination of various dis- 
positions, this article chooses to concentrate on care in order to add more nuance to studies of ethical trade that are usually concerned with normative ruminations on the idea and practices of ethical trade (e.g., Adams \& Raisborough, 2011; Archer \& Fritsch, 2010; Goodman, 2004; Low \& Davenport, 2005; Popke, 2006). Valuable as these studies are, they engage in theoretically guided empirical analyses of communication only to a limited extent. The research that looks at ethical trade communication, in its turn, zooms in on fair trade marketing and advertising, and revels in critical readings of representations deployed therein (e.g., Ramamurthy, 2012; Varul, 2008; Wright, 2004). Against this background, this study turns the spotlight away from both the normative assessments of ethical trade and the content of communication. Instead, it spotlights organisations as key actors in ethical trade and focuses on their role as mediators between producers and consumers, the role that Touri (2016) sees as only emerging.

This is important insofar as cultivating a cosmopolitan attitude among the Northern public has proved to be a thorny issue, not least because a singular "Northern" public does not exist. By zooming in on ethical trade in Poland, a country located in the periphery of the "North" and on the outskirts of the international research on ethical trade, I intend to signal the problem with the essentialising "horizontal" metageography of ethical trade. Using the quasi-geographical imaginary to organise the consumers' knowledge of the world (see Lewis \& Wigen, 1997), ethical trade draws an equatorial axis between the hemisphere of consumption, wealth and privilege (Global North), and the hemisphere of production, poverty and deprivation (Global South). Even if we leave aside the crucial issue of stigmatisation of the essentialised "South" and its people (e.g., Dogra, 2012), the homogenising image of the "North" is also problematic in that it overlooks the traditional vertical division that splits the "North" into "West" and "East". With that in mind, I seek to show how ethical trade organisations relentlessly discursively rework the idea of a supposedly wealthy and benevolent "Global North" to accommodate Polish society's deeply internalised self-image as "Eastern" and underdeveloped (see Grzymski, 2010; Kuus, 2004). In this context, every call for interest in, or action on behalf of, distant producers demands justification in the eyes of a society that considers itself poor and subordinate (Popow, 2015; Törquist-Plewa, 2002). In relation to that, I analyse the "dialectics of care", inspired by Miller's (2001) "dialectics of shopping", in ethical trade communication. Namely, I examine how ethical trade organisations negotiate in their communication among competing individual, local and distant interests in order to reach Polish society.

With all that in mind, I pose the following research question: How do ethical trade organisations negotiate between the interests of Southern producers and Polish society in their communication? Empirically, I concentrate on two interviews conducted with the representa- tives of (1) a fair trade family business, Pizca del Mundo, and (2) an NGO promoting a human-rights-based approach to development, the Institute for Global Responsibility (IGR). I selected these interviews from a larger pool of ethnographic and social media material due to their divergent rhetoric and the contrasting means of action they propose, whereby they typify two distinct approaches to ethical trade communication: while Pizca del Mundo's communication centres on the caring business relationship between producers and the firm itself, the IGR views trade within the web of global interconnectedness that envelops both producers and consumers (see Polynczuk-Alenius, 2018a). Given the very different statuses of the organisations, it is crucial to note at the outset that my objective is neither to compare nor normatively evaluate their communication approaches.

In what follows, I firstly discuss the notion of the dialectics of care in the context of ethical trade. Secondly, I present an overview of the empirical material and the discourse-theoretical approach used in the analysis. In the following sections, I review the empirically identified articulations of the dialectics of care, and discuss the oppositions and alliances charted in these articulations. Subsequently, I link the findings to the different visions of an individual subject as constructed and addressed by ethical trade organisations. Finally, in conclusion, I point out some contributions that the present article seeks to make to media and communication studies.

\section{The Dialectics of Care in Ethical Trade}

I conceptualise ethical trade as the North-South trade that recognises itself as a mediated relationship between human actors and is, as such, governed by moral principles (see Goodman, 2004). In global trade, production and consumption have been "radically separated" by an ever-growing physical, economic and moral distance between producers and consumers (Archer \& Fritsch, 2010, p. 111). In effect, the interdependence between the affluence in the North and the poverty in the South is erased, as are the processes that cause and deepen the inequalities between the hemispheres (see Tomlinson, 2011). Ethical trade is aimed at reclaiming connections between producers and consumers in the hope of substantially improving the situation of poor and underprivileged working people in the South (see Freidberg, 2003, p. 30). Largely, this reclaiming is done through communication, understood as moral education geared towards rendering the predicament of Southern producers worthy of public attention and action (see Chouliaraki, 2008).

In theorising ethical trade communication as moral education, I lean on Silverstone's (2002, p. 761) definition of mediation as a "transformative [communication] process in which the meaningfulness and value of things are constructed" (see also Carey, 2008). In the same vein, ethical trade communication seeks to re-establish among consumers the moral commitment of care, defined as both rationally and emotionally motivated con- 
cern and support for distant producers (see Milligan \& Wiles, 2010; Popke, 2006), in order to elicit society's support for the cause (see Barnett, Cloke, Clarke, \& Malpass, 2005; Tomlinson, 1999). In doing so, ethical trade communication retells the story of how North and South are inextricably connected and how they depend on each other in the global division of labour and elaborate market relations (see Calhoun, 2002; Pirotte, 2007; Popke, 2006). Here, the foundational premise is that care is contingent on the mediated familiarity with, and knowledge of, distant others (see Corbridge, 1993; Smith, 1998). Silk (1998, p. 168) describes this model of care as "third party beneficence", whereby the communication flows of mediated content from content producers to content consumers trigger an action directed at a distant context.

Tying all this together, the care proposed by ethical trade communication is cosmopolitan because it extends beyond the realm of proximate relationships with significant others towards indirect and impersonal relations with distant producers (Raghuram, Madge, \& Noxolo, 2009; Tomlinson, 1999). Crucially, however, care is not a unidirectional relation akin to charity (Silk, 1998). Rather, caring relationships acknowledge the agency of Southern producers in both shaping their own lives and influencing global trade (see Polynczuk-Alenius, 2018b), especially so in the context of global interconnectedness and interdependence (Popke, 2006; Raghuram et al., 2009). Caring relationships should also understand that the higher price set for ethical products is not benevolence, but an attempt at justice and fairness under the inequitable conditions of global trade. This call for care as universal justice and fairness might unwillingly pit the interests of distant producers against partiality towards close ones (see Corbridge, 1993; Friedman, 1991; Silk, 1998; Smith, 1998). My approach to care, enacted through the mundane practices of consumption (Raghuram et al., 2009), is inspired by Miller's (2001) "dialectics of shopping" and tries to capture the tension in ethical trade communication.

The dialectics of shopping recasts buying as an inherently moral domain in which one expresses a position towards the world and its peoples, both proximate and distant (Miller, 2001, p. 111). In Miller's view, ethical consumption is subject to haggling between caring for one's close ones, especially family members, and caring for Southern producers as distant strangers. On the one hand, caring for one's family demands careful investment of household resources in value-for-money products (Miller, 2001, p. 126). On the other hand, caring for distant strangers entails purchasing ethically produced goods that are beneficial for producers, but usually more expensive for consumers (Miller, 2001, p. 134).

Ethical trade organisations need to be mindful of this tension and continuously address it in their communication. Here, it is essential to note that while care is an attitude enacted by ethical trade organisations and proposed to consumers, the dialectics of care refers to deliberate communication tactics oriented towards the har- monising reconfiguration between care for oneself and close ones, and care for Southern producers as distant strangers. This reconfiguration is often achieved by emphasising global interdependence and interconnectedness (see Calhoun, 2002; Raghuram et al., 2009). In other words, care for distant strangers is often anchored in care for some significant others as well (see Barnett et al., 2005; Smith, 1998, p. 24). In the remainder of this article I look at how two Polish ethical trade organisations engage in the dialectics of care in conceptualising their communication practices.

\section{Discourse-Theoretical Interview Analysis}

Empirically, this article is based on the analysis of two interviews with the representatives of ethical trade organisations in Poland. Crucially, echoing the mediation theory (see Silverstone, 2002, 2005), I posit that communication is shaped by the social context in which it is carried out. The contours of ethical trade communication in Poland are, then, marked by the prevalent disinterest in, and indifference to, the consequences of consumption (see Boenning, 2009; Koszewska, 2011; PaliwodaMatiolańska, 2014). This attitude is manifest not only in the minuscule sales of fair trade products totalling some 8 million euros (personal communication with Fairtrade Polska, 2018), but also in a general moral acceptability of unethical products (Paliwoda-Matiolańska, 2014, p. 1209). In addition, the level of consumer activism is one of the lowest in Europe, engaging less than 20 per cent of the population (Stolle \& Micheletti, 2013, p. 97). With all that in mind, the interviews focused on communication as a means of engaging consumers with ethical trade and morally educating them to care for Southern producers.

The first interview was conducted with Aga, the owner of the first Polish fair trade brand, Pizca del Mundo. Here, it is crucial to note that I do not equate fair trade with ethical trade. Rather, I regard fair trade as one of the "subtypes" of ethical trade that explicitly has to do with the provision of products: "Fairtrade is an alternative approach to conventional trade and is based on a partnership between producers and consumers" (Fairtrade International, 2018). As a brand, Pizca del Mundo was established in 2012 by a firm that has been operating as a distributor of fair trade products on the Polish market since 2005. By importing fair trade ingredients directly from the certified Southern producers, the brand offers their ethical products at accessible prices. The firm is also a member of a range of associations whose goal is to promote fair trade and educate Polish consumers about global trade.

The second interview was conducted with Tomasz, a representative of an NGO, the IGR. Unlike Pizca del Mundo, which is directly involved in trade, the IGR concentrates on advocacy, campaigning and global education. Although the IGR is not formally part of the ethical trade movement, many of the issues that it deals with 
overlap with the themes of ethical trade, including tax justice, bilateral trade agreements and investment partnerships. The IGR combines these concerns with other issues related to global interdependence in a bid to "promote global solidarity and raise awareness about our shared responsibility for the world" (IGR, 2016).

Mindful of the conflictual potential of care that puts at stake the allocation of emotional and material resources among various groups (Milligan \& Wiles, 2010; Mouffe, 2005; Popke, 2006), I chose discourse theory as an appropriate analytical approach for studying the interviews (for contributions on discourse theory in media and communication studies see Carpentier, 2017; Carpentier \& De Cleen, 2007; Carpentier \& Spinoy, 2008). Discourse theory approaches discourse broadly as "a differential ensemble of signifying sequences in which meaning is constantly renegotiated" (Torfing, 1999, p. 85). This openness is due to the permanently unfinished nature of the social and to the radical unfixity of discourses (Carpentier, 2017). Meaning can be partially and temporarily stabilised via "nodal points" (Howarth, 1998), and disrupted and renegotiated through articulatory practices that establish "a relation among elements such that their identity is modified as a result of the articulatory practice" (Laclau \& Mouffe, 1985, p. 105; see also Howarth, 1998). Crucially, discourse constructs not only the meaning of social reality, but also subjects to inhabit it (see Carpentier \& De Cleen, 2007).

If, applying this frame to the present study, ethical trade communication is treated as a voluminous discourse of moral education that strives to construct its desired subjects, then care is a signifier always already open for rearticulation. With that in mind, I examined the empirical material at three different levels, loosely based on the approach outlined by Carpentier (2017). Firstly, I analysed the dialectics of care deployed by the representatives of ethical trade organisations. Secondly, I identified the relationships (oppositions and alliances) implied in these articulations of the dialectics of care (see Carpentier \& Spinoy, 2008, pp. 11-13). Thirdly, I investigated the subject positions constructed for the recipients by Pizca del Mundo's and the IGR's communication (see Carpentier \& De Cleen, 2007; Carpentier \& Spinoy, 2008).

Importantly, the analysis of this micro-set of empirical material was macro-contextual (see Carpentier \& Spinoy, 2008). In other words, the interviews were situated in the wider context of my year-long ethnographic engagement with the ethical trade movement in Poland and Finland. My involvement ranged from performing voluntary work for the organisations to participating in a variety of events, such as workshops and demonstrations, to informal conversations and fully fledged interviews with their representatives, to netnographic participant observation and administration of Facebook fan pages linked to these organisations, to formal and informal communication with ethical consumer activists.
Such a deep and prolonged immersion in the movement provided me with the insight into communication practices and conceptualisations that constitutes the empirical macro-context of this article. I selected the two interviews analysed here due to their radically different rhetoric, especially concerning the means of altering the unjust structures of global trade. The findings presented here, though, can be considered illustrative of wider tendencies also identifiable in other ethical trade organisations that I was engaged with during my fieldwork (see Polynczuk-Alenius, 2018a).

\section{Renegotiating Care}

In this section, I discuss the articulations of the dialectics of care that underlie the communication practices of Pizca del Mundo and the IGR. I begin by presenting Pizca del Mundo's tactic of embedding care for producers into the discourse of product quality. Then, I turn to the IGR's idea of interlocking care for producers with care for oneself, one's family and society through forging connections within the web of the global interdependence.

\subsection{Teetering Between Quality and Care}

Pizca del Mundo's communication continuously juggled consumers' self-care and/or care for their families and the firm's care for Southern producers. While the former was catered for by emphasising product quality (see Levi \& Linton, 2003; Low \& Davenport, 2005), care for producers enacted by the firm was tightly hooked into the business context of "[fair trade] as trade based on the fact that somebody produces and others buy...Not on a principle that somebody is better, somebody is worse, somebody is poorer, wealthier, whatever". Thus, care for producers was articulated as an inextricable component of the fair trading relationship between equal partners, not as benevolence extended towards objectified victims passively awaiting help and salvation (see Goodman, 2010).

Care was also described both as emanating from within the fair trade actors and as embedded in, and extended through, the certification schemes. For Pizca del Mundo, engagement in fair trade was at first not a conscious tie to an organisation or movement, but an intuitive business ethos: "When we were doing [fair trade] intuitively, we knew that it was something we wanted to do...But we did not know that somebody had named it already, that there were any functional solutions". However, as their network of trading partnerships, not all of which can be personal and intimate, had been growing, Pizca del Mundo benefitted from care guaranteed by formal certifications. In other words, certificates testify to the fact that producer organisations adhere to the fair trade principles, thereby serving Pizca del Mundo as institutionalised extensions of care.

As mentioned above, the consumer demand for fair trade products in Poland is very low, and Pizca del Mundo 
is acutely aware of this. Hence, the firm's primary strategy was to attract consumers from the growing "speciality coffee" segment who might buy fair trade as a corollary of their interest in premium-quality products: "I think that if someone chooses the products that we sell, it is because: (a) they are good quality, (b) they are organic, maybe (c) they are fair trade, and maybe even because they are pretty....Certainly, [fair trade] is not the main criterion" (see Radziukiewicz, 2013).

In the pursuit of quality, the firm nevertheless pragmatically assessed the taste preferences and financial capacities of Polish consumers who still valued affordability more than superior quality (see Radziukiewicz, 2013; Szubska-Włodarczyk \& Paszko, 2012). Here, it is important to bear in mind that due to fair trade's late arrival on the market at the beginning of the twenty-first century, Polish consumers are untainted by an experience of the low-quality "solidarity coffee" that the discourse of quality in fair trade marketing often seeks to remedy (Renard, 2003).

Moreover, a limit to quality was marked by the financial security and well-being of Southern producers to which Pizca del Mundo aimed to contribute. The limitations placed on the pursuit of quality by care for the producers' welfare were particularly palpable in the disregard for direct trade as an alternative to fair trade: "If the only criterion we care about is that the coffee is very good, then [direct trade] is a neat solution, because you are not tied to a producer whose coffee might turn out worse in a given year". In contrast to direct trade, one of the cardinal objectives of Pizca del Mundo was to support producers within equal and long-lasting partnerships. Thus, in the case of a less successful crop, the fair sourcing of commodities from the producers in the South would take precedence over the commercial imperative to sell a high-quality product to satisfy gourmet consumers in the North.

All in all, in terms of the objectives set for Pizca del Mundo's communication, the firm cared for, and attended to, the conscious needs of personally known producers as business subjects, rather than to an unacknowledged need of anonymous Polish consumers to be educated and moralised (see Boenning, 2009). Thus, the selling of products was communicatively prioritised over the conventional postulate of fair trade communication to "shorten the distance" and sensitise consumers to the predicament of producers. As Aga put it: "Of course we can organise photo exhibitions, lectures and whatnot. But I know [the producers] personally, and they could not care less whether we organise a meeting here, because they want to sell products". Having said that, Pizca del Mundo still engaged in raising consumer awareness, but to a lesser extent than it did in marketing.

\subsection{Forging Caring Connections}

The IGR is an example of an ethical trade organisation whose objective is to influence the structural relation- ships between the Global South and Global North in a way that empowers and emancipates the former. The principle guiding such efforts is global justice, which Miller (2001, p. 134) describes as "macro-scale care". From the IGR's point of view, the necessary changes can only be realised through and within the political process, thereby downplaying the role of individual consumption (see Maniates, 2002). Rather than endorsing ethical consumption, the representative of the IGR dismissed it as a utopic and exclusive proposition, in the Polish context attainable "only for the rich" (see Boenning, 2009; Koszewska, 2011). Thus, the IGR's communication linked care for distant strangers to more inclusive political activities, such as petitioning and participation in happenings and demonstrations. Yet, the extreme reluctance in Polish society towards politics demanded that the political character of such actions be veiled in the IGR's communication: "We do not call it political activity, although it is indeed political, but in Poland the majority is afraid of politics, deflects from it...Rather, we communicate it as civic actions".

The IGR's operations were highly reliant on public support and mobilisation. My interviewee regarded the IGR's communication efforts as being impeded by the complexity of the "neo-colonial" economic exploitation: the provenance and structure of the economic oppression in the South were not only difficult to present in an accessible form, but also problematic for Polish society to relate to and, consequently, to care for. He argued that, by and large, Poles felt no connection between their own everyday lives and the remote world of sweatshops and coffee farms. The limited awareness of, and interest in, the burning problems facing the Global South can be attributed to both the inadequacy of global education (see Boenning, 2009; Popow, 2015) and, more generally, the changing structure of employment in the modern societies whereby the majority is detached from the situation of farmers and commodity producers (Miller, 2003, p. 363). Crucially, the IGR's representative linked the absence of care for Southern producers to the financial precariousness experienced by a sizeable portion of Poles (see Eurostat, 2017):

People are self-interested. Life in Poland is difficult. Poland is a country of big social inequalities...People generally tend to their own problems. The problems of some remote countries on other continents are very abstract to them. Foreign, abstract, and they do not feel the connection, they do not feel the shared responsibility.

According to the IGR, then, care for distant strangers was contingent on two things: (1) having one's own and one's family's needs met (see Friedman, 1991), and (2) knowledge (see Corbridge, 1993; Silk, 1998; Smith, 1998). While the IGR might not have a direct influence on the former, my interviewee's conviction was that in the interdependent world the situation in Poland would only 
improve as the situation changed globally (see Raghuram et al., 2009), and that their organisation's task was to inform the society about it. Thus, for them, the concern for distant producers was virtually identical to the concern for oneself, one's close ones and proximate others: "We...link it to shared responsibility, that we stand in solidarity with these [developing] countries, because it is also in our best interest" (see Barnett et al., 2005; Smith, 1998). Thus, actions both "at home" and "at a distance" were necessary.

\section{Charting Oppositions and Alliances}

In this section, I map the relationships constructed by two distinct articulations of the dialectics of care analysed above. Two relations that I consider particularly helpful can be termed "alliance" and "opposition". In the context of ethical trade, alliances are established through the "logic of equivalence" whereby different identities are discursively brought together in a caring relationship (see Carpentier \& Spinoy, 2008; Howarth, 1998). The forming of such alliances, however, always involves the emergence of a different, negative identity (Torfing, 1999). Thus, the creation of a caring alliance entails the simultaneous construction of an uncaring opposition.

Pizca del Mundo's communication clearly positioned the firm as a primary subject invested in caring for producers (for similar findings in Hungarian fair trade organisations see Dombos, 2008). Care emanated from their moral commitment and guided the fair trade work that they carried out in a close emotional and operational alliance with producers. The degree to which the firm's care for producers was personal depended on whether the relationship involved embodied knowledge of a cooperative or was mediated through certificates issued by fair trade labelling organisations. In any case, care for the welfare of producers was materialised in the form of the fair prices paid by the company.

Pizca del Mundo performed the care work in a more or less tight alliance with other Polish fair trade organisations. This alliance was characterised by the organisations' willingness to compromise and, to an extent, overcome their ideological differences in the name of their shared concern for producers. To illustrate the workings of this alliance, Aga described the setting up of the Fair Trade Coalition in 2009 as follows "I found it very curious that devoted Catholics sat at the same table with leftist anarchists. And they were able to communicate somehow, but in the end, they did not reach an agreement...At the moment, however, we are cooperating". The operations of the alliance were complemented by the presence on the Polish market of distributors and retailers of organic and premium products, some of which might also carry a fair trade certificate. The existence of such "accidental" actors, not invested in the ideal of fair trade, allowed the firm to reaffirm its identity as a caring and ethical subject:
Maybe it is [about] different priorities, I do not know. I am under the impression that there is a world of these organisations and firms which are engaged in fair trade because it is ethically important to them. When it comes to selling, however, there are also companies primarily concerned with selling organic products which only incidentally sell fair trade products. Or they simply sell premium-quality goods, and fair trade products only incidentally.

Generally, the Polish fair trade market was described as being composed primarily of caring organisations, secondarily of "accidental" sellers, and thirdly of a rather random group of unintentional consumers interested solely in high-quality products. Through such a strong emphasis on their concern with quality and simultaneous downplaying of other possible motivations, consumers were imagined as being indifferent to the predicament of Southern producers. Thus, the firm assigned to consumers an identity that was antithetical to their own caring identity (see Carpentier \& Spinoy, 2008, p. 10).

In fact, it seemed to Pizca del Mundo that the only way to trigger consumers' interest in fair trade and in the predicament of Southern producers was through tactical "trickery". In other words, these issues had to be interwoven into topics that consumers were likely to see as more exciting (see Touri, 2016):

We conduct workshops about fair trade, but we have noticed that it is not a very sexy topic...Even when we talk about the [negative social] effects of our consumption, at the same time we tell people how chocolate is produced, and it might be interesting to them. Maybe even more interesting than the effects of consumption.

This was this kind of pragmatic thinking that also inspired the discourse of quality. Given the competing interests of fair trade producers, i.e. the financial security partially guaranteed by the fair compensation, and of consumers who desired to pay the lowest possible price (Levi \& Linton, 2003; Miller, 2003), quality appeared to be the only middle ground where these hardly reconcilable stakes could be negotiated. To be more specific, growing highquality crops helped producers to secure demand for their products and sell them at a higher price, while premium quality potentially appealed to rational self-caring consumers as an acceptable justification for a higher retail price. Hence, emphasising quality appeared to be the communication strategy that had the potential to enable an agonistic relationship between producers and consumers: even though their conflicting goals could never be fully reconciled, they were both recognised as legitimate (see Mouffe, 2005, p. 20). It is in this context that Pizca del Mundo viewed its role as a caring mediator.

Meanwhile, the IGR's communication proposed a different configuration of alliances and oppositions that built on the vision of late capitalism as being geared to- 
wards advancing the position of those who were already privileged at the cost of deepening the misery of those who were deprived (see Miller, 2003). To me, this vision seemed not only political, but also classed (see Mouffe, 1993). It fleshed out the already sharp division between a small group of beneficiaries of the current trade arrangements and a vast and interconnected group of the oppressed. In this setting, the oppressor-and hence, the uncaring opposition-was global capitalism with its trade arrangements, institutions and zealots. In particular, the transnational corporations were singled out as the primary beneficiaries of this system: "[ $I n$ the issues to do with tax justice] we mainly focus on corporations who profit immensely, but usually do not pay taxes at all in places where they generate the profits".

Against these oppressors, the global alliance was to be formed by the subjugated societies, Northern as well as Southern. This cooperation was important not least because of the capacity of the more consolidated institutions and civil societies in the North to mitigate the adverse effects of the oppression:

In reality, the [civil] society is stronger here, has a stronger voice and a better developed legal system safeguarded by a variety of institutions, and even though we are affected by the same processes, their effects are much smaller [in the North], because society, press, NGOs will not allow, for example, a corporation to do whatever it pleases. In developing countries, where the state is very weak, [people] are subjected to the same mechanisms, but they simply do not have any defence systems. We are really under the same jackboot.

In order to facilitate the emergence of such an alliance, and acting on the view of Polish society as largely oblivious to the global economic arrangements (see Popow, 2015), the IGR communication focused on exposing and expounding global interdependencies:

Our idea is to look for connections. To tell that the largest group suffering from hunger in the world are, ironically, smallholder farmers. People who produce food are those who suffer from malnutrition and hunger. And we want to find connections, [show] that they are affected by the same processes, and that the effects of industrial food systems are adverse for both them and us.

The idea here was to use communication to trigger identification and create a shared subject position for the geographically dispersed peoples dispossessed by economic globalisation: a subject position to which a common struggle for redistributive justice could be attached (see Mouffe, 2005). In Poland, the IGR imagined, the society would participate in this struggle primarily through political advocacy:
Our campaigns are aimed at mobilising the society to take action and pressure the decision-makers. While advocacy identifies needs, opportunities, moments [and] important situations, campaigns ought to mobilise people to amplify the advocacy voice and to generate pressure to force the decision-makers to take actions that are in the society's best interest.

In sum, in the context of global economy and trade, the IGR attempted communicatively to transform the current antagonism between care for oneself and one's close ones and care for distant strangers (see Miller, 2001) into a "caring chain of equivalence" whereby care for oneself would interlock with care for distant strangers (see Barnett et al., 2005). Consequently, parties vulnerable to the dislocating effects of global capitalism, individuals as well as civil society organisations and states, would form an alliance against the common adversary in the shape of oppressive capitalism (see Carpentier \& Spinoy, 2008, p. 12; Mouffe, 1993, pp. 18-19). Such a project would be a micro-scale assault on the global hegemony.

\section{Discussion}

The forthcoming discussion attempts to do two things. It presents the subject positions constructed for consumers by the two organisations and links them to the vision of an individual subject that each organisation plugged into. It also briefly reflects on how the discursive self-understanding of Polish society impinges upon ethical trade communication.

The dialectics of care articulated by Pizca del Mundo, an organisation dealing primarily with trade and sales, constructed Polish society solely as individualised consumers. To be more specific, the public was addressed as a collection of self-interested individuals whose purchasing decisions were aimed at maximising their own benefit. As buying more expensive fair trade products appeared not to be sufficiently justified by the ethical reasons alone, consumers needed to be "tricked" into supporting Southern producers through harmonising their gain with the benefit of producers. The firm regarded superior quality of products as a feature appealing to pricesensitive and self-concerned consumers (see Levi \& Linton, 2003). In that regard, Pizca del Mundo reproduced the self-fulfilling prophecy of the individualistic, rational consumers who unintentionally contribute to the collective good (see Slater, 1997). In short, consumers were addressed as individuals pursuing their own private interests and indifferent to the predicament of producers (see Barnett \& Land, 2007). The presence of such a pessimistic view might be quite surprising in a movement that defines itself by its reliance on consumer support (Fairtrade International, 2018).

A similar self-image of ethical trade activists as heroically struggling against the parochialism and selfcentrism in their society was previously identified in Hun- 
gary (Dombos, 2008). While the Hungarian ethical trade movement constantly reiterated that the "West" was an ideal to pursue and long for, the interview with Pizca del Mundo was devoid of any such references. Rather, the firm was at pains communicatively to convince the society that Poland belonged much more closely to the "West" than commonly imagined, particularly in financial terms. In this light, I maintain that the scepticism of Pizca del Mundo and some other Polish organisations towards the idea of the selfless consumer results from the deeply internalised image that they held of Polish society as being immature and still in transition into a modern, caring society capable of looking beyond selfish, individual and parochial interests (see Dombos, 2008; Kuus, 2004; Popow, 2015).

The IGR's communication, in turn, was devised to address Poles as citizens, albeit functioning in a not yet fully developed civil society (see Makowski, 2010). Unlike consumers, citizens were assigned moral virtues and ethical responsibilities that extended beyond the maximisation of their own profit. A citizen was perceived as a subject located in the political sphere in pursuit of more or less public interest (see Stolle \& Micheletti, 2013). From this originated the belief that informing Polish citizens about the interconnections and interdependence that bound them together with Southern producers and workers would potentially expand the horizon of their narrowly formulated interests to incorporate care for distant producers with whom they could empathise (Corbridge, 1993). Here, the capacity of individuals to care for distant strangers was predicated upon political awareness and imagination as well as upon a civic responsibility and capability for public engagement. The potential for care was, however, perceived as being somewhat crippled by the increasing social inequalities and the poverty and marginalisation persisting among lower social classes. While such a perception undoubtedly reflected certain lived realities, I posit that it also hinted at the benevolently and empathically articulated "internal orientalisation", whereby some segments of Polish society were regarded as non-culpable victims of both the post-socialist transition and the global corporate capitalism (Grzymski, 2010, p. 75).

In sum, the communication tactics of the two organisations, although significantly different, both considered the "local moral horizons" and personal experiences of their situated audiences (Tomlinson, 1999, p. 179). They took into account the semi-peripheral position of Poland in the world economy (e.g., Zarycki, 2014) and the associated financial dissatisfaction. Furthermore, their communication was shaped by the threefold social legacy of the relatively recent democratic transition. Firstly, Pizca del Mundo in particular was cognisant of the late arrival of consumerism in Poland (Mróz, 2010) and, therefore, communicated the purchasing of their high-quality, ethical products as "indulgent" rather than restrained consumption. Secondly, both organisations acknowledged the reluctance towards politics and low political partici- pation in the society (Makowski, 2010). While Pizca del Mundo responded by eschewing politics in their communication altogether, the IGR strategically promoted "civic", rather than political, actions. Thirdly, both organisations diagnosed the self-orientalising mindset present in Polish society: an inferiority complex manifest in a selfperception that rests on deep-seated feelings of peripherality, backwardness and underdevelopment (Grzymski, 2010; Popow, 2015; Törquist-Plewa, 2002; Zarycki, 2014). With that in mind, the IGR explicitly focused its communication on raising awareness of global interdependencies and Poland's place therein. For Pizca del Mundo, in turn, education of consumers was a long-term goal, pursued through non-commercial activities such as school workshops. It was also secondary to the financial support for distant farmers that was ensured by ethically sourcing and selling their products.

\section{Conclusion}

This article used the notion of the dialectics of care, inspired by Miller's (2001) dialectics of shopping, to inquire, by means of discourse-theoretical analysis of two interviews, how Polish ethical trade organisations used their communication to negotiate care for Southern producers and workers. Firstly, I identified two tactics through which care for Southern producers was proposed to consumers: (1) embedding it into the discourse of product quality, and (2) linking it to care for oneself, one's family and society by raising awareness of the global interconnectedness. Secondly, I examined the relationships constructed by these articulations of the dialectics of care. Again, I uncovered two radically different approaches. The first one located Pizca del Mundo in a caring alliance with producers and positioned consumers as the inherently self-interested, uncaring opposition. Here, product quality emerged as the only possible common ground on which the conflicting interests of producers and consumers could be negotiated. In this context, communication served Pizca del Mundo to "trick" consumers into supporting fair trade. The second dialectics of care sought to forge a caring alliance between Polish society and distant producers on the basis of being affected by the same global economic processes and mechanisms, albeit to different degrees. Thus, the goal of IGR's communication was discursively to create a caring chain of equivalence, a global class of the oppressed, uniting Northern consumers and Southern producers in opposition to transnational corporations and other institutions of global capitalism.

This article sought to contribute to the nuancing of the usually normative research on ethical trade (e.g., Adams \& Raisborough, 2011; Archer \& Fritsch, 2010; Goodman, 2004; Low \& Davenport, 2005; Popke, 2006) through empirically investigating how organisations appropriate elements of the discursive repertoire of ethical trade, particularly care and the "Global North", into their actual communication practices. Theoretically, it 
proposed and conceptualised care as one of the moral dispositions put forward by ethical trade communication. Thus, instead of assuming that a particular moral outlook is embedded in the idea of ethical trade itself and automatically transmitted through the various practices associated with it, this article inquired how care was communicatively constructed and what subjects it called into being. By adopting a firmly empirical approach, this article demonstrated how normative concepts are negotiated in the actual communication practices "on the ground". For media and communication studies, and the ethics of communication in particular, this article reaffirmed the significance of analysing communication in the broadly understood social context in which it is produced (Silverstone, 2005). Finally, given the negligible interest of Polish media in global economy and ethical trade, this study necessarily transposed the ethical notion of mediation to the mundane communication practices of organisations outside the media sector. By removing the concept of mediation from the familiar domain of journalism and media content (Chouliaraki, 2008; Silverstone, 2002, 2005), this study set a modest example for research concerned with ethics of communication beyond media organisations and in the context of niche social causes.

\section{Acknowledgements}

I would like to thank the two anonymous reviewers for their helpful suggestions and encouraging comments.

\section{Conflicts of Interest}

The author declares no conflicts of interest.

\section{References}

Adams, M., \& Raisborough, J. (2011). Encountering the fairtrade farmer: Solidarity, stereotypes and the self-control ethos. Papers on Social Representations, 20(1), 8.1-8.21.

Archer, C., \& Fritsch, S. (2010). Global fair trade: Humanizing globalization and reintroducing the normative to international political economy. Review of International Political Economy, 17(1), 103-128.

Barnett, C., Cloke, P., Clarke, N., \& Malpass, A. (2005). Consuming ethics: Articulating the subjects and spaces of ethical consumption. Antipode, 37(1), 23-45.

Barnett, C., \& Land, D. (2007). Geographies of generosity: Beyond the "moral turn". Geoforum, 38(6), 1065-1075.

Boenning, K. (2009). The introduction of fair trade in Poland: Opportunities and challenges. BANWA, 6(2), 87-98.

Calhoun, C. J. (2002). Imagining solidarity: Cosmopolitanism, constitutional patriotism, and the public sphere. Public Culture, 14(1), 147-171.

Carey, J. W. (2008). Communication as culture: Essays on media and society (Revised Edition). London: Taylor \& Francis.

Carpentier, N. (2017). The discursive-material knot: Cyprus in conflict and community media participation. New York, NY: Peter Lang.

Carpentier, N., \& De Cleen, B. (2007). Bringing discourse theory into media studies: The applicability of discourse theoretical analysis (DTA) for the study of media practices and discourses. Journal of Language and Politics, 6(2), 265-293.

Carpentier, N., \& Spinoy, E. (2008). Introduction: From the political to the cultural. In N. Carpentier \& E. Spinoy (Eds), Discourse theory and cultural analysis (pp. 1-26). New Jersey, NJ: Hampton Press.

Chouliaraki, L. (2008). The media as moral education: mediation and action. Media, Culture and Society, 30(6), 831-852.

Corbridge, S. (1993). Marxisms, modernities, and moralities: Development praxis and the claims of distant strangers. Environment and Planning D: Society and Space, 11(4), 449-472.

Dogra, N. (2012). Representations of global poverty: Aid, development and international NGOs. London: IB Tauris.

Dombos, T. (2008). "Longing for the West": The geosymbolics of the ethical consumption discourse in Hungary. In G. De Neve, P. Luetchford, J. Pratt, \& D. C. Wood (Eds), Hidden hands in the market: Ethnographies of fair trade, ethical consumption, and corporate social responsibility (pp. 123-141). Bingley: JAI Press.

Eurostat (2017). Wages and labour costs. Eurostat statistics explained. Retrieved from http://ec.europa.eu/ eurostat/statistics-explained/index.php/Wages_and _labour_costs

Fairtrade International. (2018). What is Fairtrade? Retrieved from http://www.fairtrade.net/aboutfairtrade/what-is-fairtrade.html

Freidberg, S. (2003). Cleaning up down South: Supermarkets, ethical trade and African horticulture. Social \& Cultural Geography, 4(1), 27-43.

Friedman, M. (1991). The practice of partiality. Ethics, 101(4), 818-835.

Goodman, M. K. (2004). Reading fair trade: Political ecological imaginary and the moral economy of fair trade goods. Political Geography, 23(7), 891-915.

Goodman, M. K. (2010). The mirror of consumption. Geoforum, 41(1), 104-116.

Grzymski, J. (2010). O powrocie Polski do Europy: Przyczynek do rekonceptualizacji dychotomii centrumperyferie [On the return of Poland to Europe: A contribution towards the reconceptualisation of the centreperiphery dichotomy]. Kultura i Polityka, 7, 68-82.

Howarth, D. (1998). Discourse theory and political analysis. In E. Scarbrough \& E. Tanenbaum (Eds), Research strategies in the social sciences: A guide to new approaches (pp. 268-293). Oxford: Oxford University Press. 
Hudson, I., \& Hudson, M. (2003). Removing the veil? Commodity fetishism, fair trade, and the environment. Organization and Environment, 16(4), 413-430.

Institute for Global Responsibility. (2016). Misja [Mission]. Retrieved from http://igo.org.pl/o-igo/misja

Koszewska, M. (2011). The ecological and ethical consumption development prospects in Poland compared with the Western European countries. Comparative Economic Research, 14(2), 101-123.

Kuus, M. (2004). Europe's eastern expansion and the reinscription of otherness in East-Central Europe. Progress in Human Geography, 28(4), 472-489.

Laclau, E., \& Mouffe, C. (1985). Hegemony and socialist strategy: Towards a radical democratic politics. London: Verso.

Levi, M., \& Linton, A. (2003). Fair trade: A cup at a time? Politics \& Society, 31(3), 407-432.

Lewis, M. W., \& Wigen, K. E. (1997). The myth of continents: A critique of metageography. Berkley, CA: University of California Press.

Low, W., \& Davenport, E. (2005). Has the medium (roast) become the message? The ethics of marketing fair trade in the mainstream. International Marketing Review, 22(5), 494-511.

Makowski, G. (2010). Civil society in Poland: Challenges and prospects. In J. Kucharczyk \& J. Zbieranek (Eds.), Democracy in Poland 1989-2009: Challenges for the future (pp. 115-127). Warsaw: Institute of Public Affairs.

Maniates, M. (2002). Individualization: Plant a tree, buy a bike, save the world? In T. Princen, M. Maniates, \& K. Conca (Eds.), Confronting consumption (pp. 43-66). Cambridge, MA: The MIT Press.

Miller, D. (2001). The dialectics of shopping. Chicago, MI: University of Chicago Press.

Miller, D. (2003). Could the Internet defetishise the commodity? Environment and Planning D: Society and Space, 21(3), 359-372.

Milligan, C., \& Wiles, J. (2010). Landscapes of care. Progress in Human Geography, 34(6), 736-754.

Mouffe, C. (1993). The return of the political. London: Verso.

Mouffe, C. (2005). On the political. London: Routledge.

Mróz, B. (2010). Consumerism vs. sustainability: The emergence of new consumer trends in Poland. International Journal of Economic Policy in Emerging Economies, 3(1), 1-15.

Paliwoda-Matiolańska, A. (2014). Konsumeryzm świadomy społecznie w Polsce [Conscious consumerism in Poland]. Marketing i Rynek, 2014(8), 1204-1210.

Pirotte, G. (2007). Consumption as a solidarity-based commitment. In E. Zaccai (Ed.), Sustainable consumption, ecology and fair trade (pp. 127-143). London: Routledge.

Polynczuk-Alenius, K. (2018a). Ethical trade communication as moral education: A discourse analysis of mediation in context (Doctoral dissertation). University of Helsinki, Helsinki, Finland. Retrieved from https://helda.helsinki.fi/handle/10138/233793

Polynczuk-Alenius, K. (2018b). Mediating the agency of distant others: Proper distance in fair trade communication on Facebook. International Journal of Cultural Studies, 21(2), 155-172.

Popke, J. (2006). Geography and ethics: Everyday mediations through care and consumption. Progress in $\mathrm{Hu}$ man Geography, 30(4), 504-512.

Popow, M. (2015). Postcolonial Central Europe: Between domination and subordination. The example of Poland. The KULT. Journal for Nordic Postcolonial Studies at Roskilde University, 12, 96-118.

Radziukiewicz, M. (2013). Postrzeganie idei Sprawiedliwego Handlu: Zachowania i postawy polskich konsumentów [Perception of fair trade: Behaviours and attitudes of Polish consumers]. Retrieved from http://old.ibrkk.pl/f/?Radziukiewicz-Raport-handelwewnetrzny-2013.pdf

Raghuram, P., Madge, C., \& Noxolo, P. (2009). Rethinking responsibility and care for a postcolonial world. Geoforum, 40(1), 5-13.

Ramamurthy, A. (2012). Absences and silences: The representation of the tea picker in colonial and fair trade advertising. Visual Culture in Britain, 13(3), 367-381.

Raynolds, L. T., \& Bennett, E. A. (2015). Introduction to research on fair trade. In L. T. Raynolds \& E. A. Bennett (Eds.), Handbook of research on fair trade (pp. 3-23). Cheltenham: Elgar.

Renard, M.-C. (2003). Fair trade: Quality, market and conventions. Journal of Rural Studies, 19(1), 87-96.

Silk, J. (1998). Caring at a distance. Ethics, Place \& Environment, 1(2),165-182.

Silverstone, R. (2002). Complicity and collusion in the mediation of everyday life. New Literary History, 33(4), 761-780.

Silverstone, R. (2005). The sociology of mediation and communication. In C. Calhoun, C. Rojek, \& B. Turner (Eds.), The Sage handbook of sociology (pp. 188-207). London: SAGE.

Slater, D. (1997). Consumer culture and modernity. Cambridge: Polity.

Smith, D. M. (1998). How far should we care? On the spatial scope of beneficence. Progress in Human Geography, 22(1), 15-38.

Stolle, D., \& Micheletti, M. (2013). Political consumerism: Global responsibility in action. New York, NY: Cambridge University Press.

Szubska-Włodarczyk, N., \& Paszko, E. (2012). Analiza zakupu produktów sprawiedliwego handlu [An analysis of buying fair trade products]. Wiadomości Statystyczne, 6, 57-67.

Tomlinson, J. (1999). Globalization and culture. Cambridge: Polity Press.

Tomlinson, J. (2011). Beyond connection: Cultural cosmopolitan and ubiquitous media. International Journal of Cultural Studies, 14(4), 347-361. 
Torfing, J. (1999). New theories of discourse: Laclau, Mouffe and Žižek. Oxford: Blackwell.

Touri, M. (2016). Development communication in alternative food networks: Empowering Indian farmers through global market relations. The Journal of International Communication, 22(2), 209-228.

Törquist-Plewa, B. (2002). The complex of an unwanted child: The meanings of Europe in Polish discourse. In M. af Malmborg \& B. Stråth (Eds.), The meaning of
Europe: Variety and contention within and among nations (pp. 215-241). Oxford: Berg.

Varul, M. Z. (2008). Consuming the campesino. Cultural Studies, 22(5), 654-679.

Wright, C. (2004). Consuming lives, consuming landscapes. Journal of International Development, 16(5), 665-680.

Zarycki, T. (2014). Ideologies of eastness in Central and Eastern Europe. London: Routledge.

\section{About the Author}

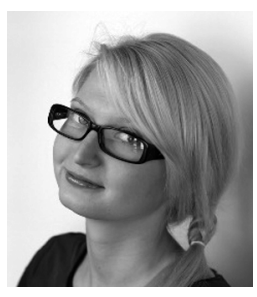

Kinga Polynczuk-Alenius is a researcher in media and communication at the Faculty of Social Sciences, University of Helsinki. She has recently defended her doctoral dissertation titled Ethical trade communication as moral education. Her articles have been published in academic journals such as Globalizations and the International Journal of Cultural Studies. Kinga is currently launching a new project on everyday mediations of racism and nationalism in Poland. 